\title{
Lexicography and the history of culture (The case of Teodor Corbea's Romanian-Latin Dictionary)
}

\author{
Alin-Mihai Gherman * \\ Faculty of History and Philology, "I Decembrie 1918” University, Str. Unirii 15-17, 510009 Alba Iulia, Romania
}

\section{Article info}

History:

Received September 17, 2021

Accepted October 6, 2021

Published December 12, 2021

Key words:

philology

text editing

old documents

\begin{abstract}
This study aims at pointing to the cultural dimensions of lexicography, both by revealing the cultural content of lexicographic works and the authors' cultural horizons and by searching for a precise cultural motivation for compiling dictionaries. One such particular exercise is applied to Teodor Corbea's LatinRomanian Dictionary, elaborated between 1691-1702. Our study focuses on the encyclopædic character of this work and its relations with the Greco-Roman culture. It also analyses the Latin-Romanian similarities and the way the Romance character of the Romanian language is reflected.
\end{abstract}

\section{Introduction}

Regarded as a less spectacular part of the history of linguistics, the history of lexicography did not enjoy a special interest on the part of specialists. Beyond their accuracy, the few attempts related to lexicography consist, for the most part, in listing the works as such, in evoking their dimensions, mentioning the shortcomings of each or a group of them and the echo a dictionary or a group of dictionaries had for posterity.

1.1. As far as Romanian lexicography is concerned, beyond the concise character proposed by the very title of the book, a remarkable work such as Schiță de istorie a lexicografiei românești [Brief History of Romanian Lexicography] (Seche, 1966) reveals less than enough about the cultural context and reasons for writing such works, proving rather a kind of "Guinness Book" in the field of local lexicography, mentioning, for instance, the first German-Romanian bilingual dictionary, but failing to hint at the reasons for compiling such work. This is quite an important aspect, since, in principle, writing a lexicographical work requires a considerable amount of work and offers considerably less satisfaction to the authors-who, more than often in the case of our old literature, remain anonymous, unless the work is attributed to the last copyist whose signature it bears. Let us consider the case of our modern culture, where barely anyone remembers the names of Florian Aaron or Georges Hill, co-authors of the well-known Vocabular franțezo-românesc după cea din urmă ediție a dicționarului de Academia Franțozească [French-Romanian Vocabulary after the Last Edition of the French Academy Dictionary], volumes 1-2 (Vocab. 1840-1841), commonly associated only with the name of Petrache Poenaru, who, in his capacity as director of "Saint Sava" College, was the first to sign it. Equally well-known is the name of George Baritiu, who contributed to the writing of the second volume of the first academic dictionary of the Romanian language elaborated primarily by August Treboniu Laurian and Ioan Massim.

\section{Old Romanian bilingual lexicography}

Resuming the statement of Henricus Stephanus (Henri Estienne) in the famous Thesaurus grece lingue (TLG), according to which writing a dictionary is harder than rowing in galleys, we believe that one must look for the general and particular motivation of this seemingly fastidious endeavour. Obviously, such

^Email address: diortositor@gmail.com. 
Alin-Mihai Gherman

strenuous effort was motivated neither by material gain nor by the promise of fame or public recognition. At least in the case of bilingual lexicography the cause should be related to the need to access a foreign culture, whereas in the case of monolingual dictionaries the motivations are yet more subtle, pertaining to the development of national identity and the interest for one's own people. The context in which a lexicographic work is elaborated, a context that is hardly ever incidental and thus requires decoding, as well as the cultural horizon reflected in the respective work should be perceived as connected to the history of culture. To support our viewpoint, we shall focus on a few moments in the development of Romanian lexicography, the historical context and the motivation behind the creation of some of these works.

2.1. Slavonic-Romanian lexicography, which manifested itself in the second half of the $17^{\text {th }}$ century and the first half of the $18^{\text {th }}$ century is closely related, on the one hand, to the translation of liturgical texts into Romanian and, on the other hand, as indicated by the content of the Slavonic-Romanian glossaries, to the translation of a large volume of Slavonic property documents, a common practice at the time.

2.2. The two lexicographic works edited in Țara Hațegului and Eastern Banat in the second half of the $17^{\text {th }}$ century, Anonimus caransebesiensis and Lexicon Marsilianum, regarded as "accidents" or curiosities of our old literature, should be perceived as representing a coherent aspect of the phenomenon of integration of a group of free Romanians living in the urban environment of Caransebeș, Lugoj or Hațeg, part of the structure and culture of the Principality of Transylvania (see Gherman, 2019).

2.3. Likewise, the Transylvanian School lexicography, in which the number of dictionaries and glossaries using Latin prevailed, should be regarded not only from a general cultural perspective-Latin was still the language of European culture and until towards the end of the $18^{\text {th }}$ century it was the language that unified the multiethnic Habsburg Empire-but also from the perspective of the political programme of the movement aimed at proving the Romance appurtenance of the people and implicitly the Latin character of the language as an argument in favour of the Romanians' right to enjoy the same privileges as the other political nations (Hungarians, Saxons and Szeklers) had in the Principalities, according to the Medieval legislation still in force at the time. Thus, for the Transylvanian scholars, lexicography turned into a political weapon ${ }^{1}$.

2.4. An extension of this perspective seemed normal for two Transylvanian scholars, namely Alexandru Treboniu Laurian and Ioan Massim, as the fight of Romanians from Transylvania was a logical continuation of the efforts supported by the Supplex generation in achieving the first dictionary of the Romanian language under the patronage of the Romanian Academy. However, on the opposite side of the mountains, the Transylvanians' political programme did not have any echo for scholars such as Alexandru Odobescu or Bogdan Petriceicu Hasdeu, so that the misunderstandings that occurred after the publication of this work are related to a lack of comprehension rather than to the shortcomings of the work itself.

2.5. A last example: Ienăchiță Văcărescu compiled two dictionaries, a German-Romanian and a RomanianGerman dictionary (both preserved in manuscripts, which, in our opinion, deserve a future editing), in which, quite unusually, the German lexicon is phonetically transcribed with Cyrillic characters. An explanation for this peculiarity can be traced in the political context of the second half of the $18^{\text {th }}$ century, as Oltenia had been occupied by the Austrians for a long time. The two works had a precise, practical destination, being aimed at facilitating communication with the temporary occupants.

\footnotetext{
${ }^{1}$ We should note that the glossary, the dialogues and the words used to illustrate the structure of the Romanian language in Elementa lingue daco-romane sive Valachice, published by Samuil Micu and Gheorghe Șincai in Vienna, in 1780, contain almost exclusively words of Latin origin. This observation is also valid for the second edition, issued under the name of Gheorghe Șincai.
} 


\section{Teodor Corbea's Latin-Romanian Dictionary}

Teodor Corbea's Latin-Romanian Dictionary ${ }^{2}$ (entitled by the author Dictiones latine cum valachica interpretatione) holds a special place in the old Romanian literature and lexicography due to its character, being the most extensive lexicographic work compiled in Romanian before the second half of the $19^{\text {th }}$ century which contained, as did Biblia de la București [The Bible from Bucharest] (1688), the vastest lexical inventory of an old text.

3.1. Corbea's dictionary is the author's autograph manuscript, but it is not dated. The following mention appears in the end: "La tălmăcirea acestuiu lixicon ostenitu-s-au din plata părintelui Mitrofan, episcopul de Buzău, Todor Corbea, sîn iermonah Ioasaf din Braşov" [This lexicon was translated by Teodor Corbea, son of hieromonk Ioasaf from Braşov, paid by father Mitrofan, Bishop of Buzău]. As the precise date is unknown, considering the period in which Mitrofan was the Bishop of Buzău, Teodor Corbea's dictionary was definitely written sometime between 1691 and 1702. As Teodor Corbea travelled extensively to Russia and Transylvania starting with 1698, he obviously could not have written such a vast work during his travels, which entitles us to believe that the dictionary was actually elaborated in the first part of this period.

3.2. Mitrofan, the Bishop of Buzău, is one of the most complex personalities of our culture in the second half of the $17^{\text {th }}$ century and the early $18^{\text {th }}$ century: he collaborated closely, while he was Bishop of Huşi, with Metropolitan Dosoftei; after Dosoftei's second exile, he took refuge in Wallachia and was the corrector of The Bible from Bucharest and other books printed during the first years of Constantin Brîncoveanu's reign. The mixture of dialectal forms specific to Wallachia and Moldova in the first complete printed edition of the Bible in Romanian is attributed to him. As Bishop of Buzău (1691-1702), where he established a printing house, he edited several works of great importance for the Orthodox Church, and especially for supporting the Orthodox spirit: the first Romanian translation of Pravoslavnica mărturisire [The Orthodox Confession] (due to Brîncoveanu's faithful collaborator and official chronicler, Radu Greceanu, who, together with his brother, contributed to the elaboration of the printed text of the Bible), the first printed edition of Menaion (1698, in which there appear some text fragments from Metropolitan Dosoftei's Viața şi petreacerea svinților [The Life of Saints], an aspect which has not been revealed before), a Slavonic and Romanian Molitvenic (1699), Octoib ce să zice osmoglasnic [Octoechos] (1700), Triod, ce să zice tripeasneță [Triodion] (1700), a Slavonic and Romanian Euhologhion, adecă molitvenic [Euchologion] (1701), a Slavonic and Romanian Pentekostarion (1701), Psalter (1701), Învățătura preoților pre scurt de şapte taine [Short Teaching on the Seven Mysteries for Priests] (1702), Sfinta şi dumnezeiasca liturghie [The Holy and Divine Liturgy] (1702). At least some of the dedicatory lyrics in these printed works and some fragments in the life of saints from the Menaion can be attributed, as indicated by the linguistic forms and versification style, to Teodor Corbea. The fact that he was asked by Mitrofan to write this dictionary was motivated by his solid command of the Latin language. He had actually been appointed "sicritariu de taină" (personal secretary) of Constantin Brîncoveanu and had carried out, on behalf of the prince, the Cantacuzino family and himself a vast correspondence in Latin with the Habsburg authorities and the Transylvanian Prince Francisc Rákóczi the $2^{\text {nd }}$ (see Pippidi, 2005).

3.3. Originally from Șcheii Brașovului, son of one of the priests from the local "Saint Nicholas" Church and brother of David, a well-known diplomat of the time, Teodor Corbea was a good connoisseur of Latin, Slavonic and Hungarian. Most probably he had studied the first two languages at the Kiev Academy. His excellent command of the Latin language recommended him as secretary of Prince Constantin Brîncoveanu, and a close collaborator of the Cantacuzinos. After his flight to Russia, following Peter the Great's 1711 campaign in Moldova and Wallachia, he was also a close collaborator of the Tsar of Russia.

${ }^{2}$ Published by us in 2001 at the Clusium Publishing House in Cluj-Napoca. A new edition, accompanied by the Romanian lexis index and a $\mathrm{CD}$ with the manuscript facsimiles is about to be completed. 
He did not consider himself the author of the dictionary, but rather its translator, as evidenced by the entry Theodorus in the dictionary: "Theodorus, g.m. ${ }^{3}$ nume de bărbaţi de obşte; item: numele acestui de pă urmă, care această carte de pă latinie şi ungurie o au tălmăcit rumîneaşte" [name for men; item: name of the above-mentioned, who translated this book from Latin and Hungarian into Romanian]. The source of the dictionary is specified by the author himself: it is the third edition of Albert Szenczi Molnár's Latin-Hungarian Dictionary (see DUL) ((who, in turn, used Dictionarium latino-germanicum by Petrus Dasypodius and Petrus Cholinus, one of the many editions of Calepinus or Dictionarium latinogermanicum, written by Johannes Frisius), with entries such as: "Itorsium, g.n. orăşăl în țînutul domnilor norimbergheani, în care acest noriberghean svat cinsteş bogată academie au zidit în numărul anilor 1575, unde acest Lixicon l-au scris Albertus Molnar în numărul anilor 1603" [a small town in the land of the lords of Nuremberg where a rich academy was built in the year 1575, where Albertus Molnar wrote this Lexicon in the year 1603] or: "Argentina, g.f. et Argentoratum tare oraş al Țărei Nemțeşti lîngă apa Rhenus, în ţînutul Alsaţiei. Acolo ca acela înalt turn iaste şi bisearecă înfrîmşețată, cît în Europa altă bisearică sau turn aseamine acestora nu iaste. Iaste iarăş acolo o academie vestită, în care de demult mulți înțelepți oameni s-au învățat, unde şi eu, care această carte am scris (adecă Albert Molnaru) trei ani şi jumătate am lăcuit în vreamea copilăriei” [a mighty town in Germany near the Rhine River, in the region of Alsace. There you can find a tall tower and a beautiful church as nowhere else in the whole Europe. There is also a famous Academy where many famous people studied in the past. I, Albert Molnaru, who wrote this book, also lived there for three years and a half when I was a child]. However, this is not a mechanical translation of the Hungarian dictionary, as Teodor Corbea eliminated several entries that he probably considered irrelevant, he shortened a series of other entries and added some others to Szenczi Molnár's list, also providing their Romanian equivalents.

\section{The encyclopæedic dimension of the dictionary}

The comparison of the lists of Latin words included in Szenczi's and Corbea's dictionaries indicates, however, that the latter had a creative attitude, both by eliminating some entries and by selecting, within the entries, the meanings for which he provided the Romanian equivalents, occassionally adding entries he considered relevant, due to his experience as Latin secretary of Constantin Brîncoveanu or of the Cantacuzinos.

4.1. The fact that a considerable number of entries referring to ancient Greco-Roman culture were preserved proves Teodor Corbea's adherence to the current of modernization of our culture known as "Romanian humanism", placing his works besides the contributions of Constantin Cantacuzino and even those of Dimitrie Cantemir, because his dictionary acquires, along with the character of a bilingual dictionary, a pronounced encyclopædic dimension.

4.2. In Teodor Corbea's work, for the very first time in the Romanian culture, the Rome of martyrdoms (seen before him, from a Christian point of view, only as a new apocalyptic Babylon, and from the point of view of the Eastern Church, as a centre of religious schism) becomes the glorious city of ancient culture. Such research is only possible by conducting a thorough text analysis, and Teodor Corbea's Latin-Romanian Dictionary seems to provide the ideal material for such an approach. The confrontation between the two perspectives over the Eternal City produced an equally strong debate in the western world, during the Humanist and Renaissance periods, and also afterwards.

4.3. One should note from the very beginning that there are very few references to Christianity and Roman

\footnotetext{
${ }^{3}$ As Corbea's dictionary is written with Latin characters (as it is normal in its Latin section) incidentally also in the Romanian section (where mostly Cyrillic characters are used), we opted for transcribing all Latin characters, wherever they might be placed within the text, in bold letters.
} 
martyrdoms ${ }^{4}$ : "Bibiana, g.f. o fată creştină rimleancă, care supt Iuliian s-au omorît pentru căce că au ajutat tătîni-său să îngroape trupurile ceale moarte ale creştinilor" [a Christian girl from Rome who was killed under Julius' rule because she helped her father burry the dead body of the Christians], "Chrysantus, g.m. un voinic de la Alixandriia, care la Roma pentru leagea credinței creştineşti s-au omorît" [a young man from Alexandria who was killed in Rome for keeping his Christian faith], "Betlehem, g.f. [n.n.: recte: Bethleheem] oraş al Iudeii, de-acolo pînă în Ierusalim 7 mile de loc, în care Domnul nostru Isus Hristos s-au născut" [a city of the Kingdom of Judah, 7 miles far from Jerusalem, where our Lord Jesus was born], "Bethsames, g.f. oraş al Galileei în care Domnul nostru Isus Hristos, precum spun scripturile, multe minuni au făcut" [a town in Galilee where our Lord Jesus Christ, as the Scriptures say, performed many miracles], "Origenes, g.m. numele unui dascal creştin" [the name of a Christian teacher], etc. The emperors that persecuted the Christians are not necessarily depicted in a negative light, as in the hagiographic literature: "Decius, g.m. nume al unui rimlean" [name of a Roman], "Julianus, g.m. numele unui împărat rimlenesc" [name of a Roman emperor], etc. In the case of Nero, the negative image can be traced from the texts of the ancient historians rather than from the lives of the saints: "Nero, - onis, g.m. numele unui împărat rimlean nemilostiv" [name of a merciless Roman emperor].

4.4. The negative references to paganism in the ancient word are also sporadic: "Arsenotheles, g.m. pl. dumnezăi au fost pre carii i-au socotit păgînii a avea năravuri şi bărbăteşti şi muiereşti” [gods believed by the pagans to have both masculine and feminine habits], "Comus, g.m. dumnezău ${ }^{5}$ în zîlele păgînilor al nuntelor de noapte şi al jocurilor" [pagan god of night weddings and dances], "diffareatio, g.f. jîrtvă au fost la păgîni spre despărțîrea casătoriei” [pagan sacrifice for divorce], "ethnicus, -a, -um păgîn, -că” [pagan], "Portunu, g.m. dumnezăul vînslarilor şi al vadurilor au fost întru păgînime” [he was the pagan god of the waters and boatmen], "Saturnus, g.m. una dintre 7 planite [one of the seven planets]; item: tatăl lui Iupiter, Iunei, al lui Neptunus şi Pluto, pre care în păgînime l-au țînut dumnezău” [father of Jupiter, June, Neptune and Pluto, who was thought by the pagans to be a god], "Tutanus, g.m. dumnezău au fost între păgînimea rimlenească, pre care în nevoile ceale prea mari l-au chiemat într-ajutori” [Roman pagan god called for help in times of great misfortune], "Vertumnus, g.m. dumnezău au fost întru păgînime al învîrtirei, al întoarcerei" [pagan god of turning, of returning], "Vitunus, g.m. dumnezău păgînesc de demult au fost, pre care l-au socotit dătători de viiață" [he was once a pagan god, the pagans thought him to be a life-giver].

4.5. The geographical horizon of Corbea's Romanian-Latin Dictionary is limited to the ancient perspective, as he only mentions the three continents known of in Antiquity (Asia, Africa and Europe), with a focus on the European continent: "Africa, g.f. o parte dintre trei părți a ocolului pămîntului” [one of the three parts of the Earth], "Aphrica, g.f. a treia parte a acestui pămînt” [the third part of the Earth], "Asia, g.f. una dintre ceaste 3 părți ale lumiei" [one of the three parts of this world]; a slight hesitation triggered by some vague knowledge of the new geographical discoveries occurs in the definition of Europe: "Europa, g.f. a treaea sau a patra parte a ceștii lumi, în care iaste Țara Nemțască, Țara Ungurească și Țara Italiei, de la Nemțasca Mare pînă la Marea-din-Mijlocul-Pămîntului și pînă la apa Tanaisului” [the third or the fourth part of this world that contains Germany, Hungary and Italy, from the German Sea to the Middle Sea and to the water of Tanais]. This eurocentrist perspective rooted in the ancient culture explains why Italy is depicted as better known than any other peripheral region of the continent; Rome is the centre of Italy, as implied by the following definition: "Italia, g.f. Italiia, în Europa între Marea Adriaticum şi Tyrhenum, care are oraş mare pă Roma" [Italy, situated in Europe between the Adriatic Sea and the Tyrrhenian Sea, which has a big city, Rome]. It becomes an essential reference point, the distance from and proximity to

\footnotetext{
${ }^{4}$ This fact can also be explained by the source of Corbea's dictionary: as a reformed (Calvinist), Szenczi Molnár ignored for the most part the lives of the saints and the martyrdoms of the first period of Christianity.

${ }^{5}$ We should note that Teodor Corbea did not use different words to designate the gods of Antiquity and the Christians' God, using the same word for both notions. For 'goddess' he uses the term: dumnezăoaie, which is not known to have been used previously in Romanian.
} 
it being very important ${ }^{6}$.

4.6. The Roman history is equally well-known ${ }^{7}$, yet for Teodor Corbea the true Antiquity relates to culture. He knows the names of the great Latin writers: Cicero ${ }^{8}$, Horatio ${ }^{9}$, Ovid $^{10}$, Juvenal ${ }^{11}$, Lucretius ${ }^{12}$, Titus Livius ${ }^{13}$, etc. He had extensive knowledge about Vergilius and his books ${ }^{14}$, while Cicero's Latin (he expressly quoted linguistic forms from Cicero's works) is a point of reference to which he turns again and again.

4.7. Beyond the world of the Latin culture, the author mentioned most often is certainly Homer ("Homerus, g.m. numele unui petic elin vestit şi înțelept" [the name of a famous and wise Greek poet]), from

6"Beletra, g.f. oraş italienesc, nu departe de la Roma” [Italian town, not far from Rome], "Bovillix, g.f. pl. oraş aproape de Roma" [a town near Rome], "Præneste, g.f. oraş au fost italienescu, nu departe de Roma" [it was an Italian town not far from Rome], "Tybur, -ris, g.m. oraş italienesc aproape de Roma" [Italian town close to Rome], "Ostia, g.f. oraş italienesc dincolo de Roma, unde cură Tiberisul în mare" [Italian town beyond Rome, where the Tiber flows into the sea]. Rome itself is well-known to Corbea: "Æquimelium, g.n. numele unui loc la Roma” [name of a place in Rome], "Agrosus, g.m. dealul pă care acmu zace Roma" [the hill on which Rome is located], "Argiletum, g.n. un loc în Roma nu dăparte de la Palațium” [a place in Rome not far from Palatium], "Buthrotum, g.n. loc obăgit la Roma" [a place conquered by Rome], "Carmentalis, -e, g.f. [n.n.: recte: Carmentalia] nume a unii porț de la Roma" [name of a gate in Rome], "Carseoli, g.m. pl. sat de la Roma” [a village in Rome], "circus, g.m. [...] în Roma o zidire mare rotească, loc de privirea jocurilor" [in Rome, a great round building, from which the games were watched], "Cispius, g.m. un munte la Roma" [a mountain in Rome], "Coelium, g.m. un munte la Roma [a mountain in Rome], vide: Cæelius", "Fontinalis, g.f. nume al porței de la Roma care cu alt nume să zîce Capena" [name of a gate in Rome, otherwise named Capena], "Fori, -orum [...] loc de privit au fost în Roma" [it was a place for viewing in Rome].

7 “Ariobarzanes, g.m. nume al unui împărat de la Machidoniia, care romanilor au fost priiatin bun" [name of an emperor from Macedonia, a good friend of Romans], "Asinius, g.m. orator roman, frate lui Avgust" [a Roman speaker, brother of Augustus], "Atratimus, g.m. procator de la Roma au fost" [he was a couselor from Rome], "Cæxar, g.m. nume al citorva romani de pre carii pre toț împărații rimleneşti îi număsc Chiesar" [name of some Romans after which all the Roman emperors were named Caesar], "Catilina, g.m. un domn de la Roma viclean, care au fost nevoitori spre aducerea răului rimlenescu” [a sly ruler from Rome, who endeavored to do harm to the Roman people], "centumviri, g.m. pl. o sută de oameni județi de la Roma” [one hundred judges from Rome], "Cethegus, g.m. pîrgari de la Roma” [a consul from Rome], "Claudia, g.f. o fămeaie rimleancă; iarăş: o seminție vestită la Roma” [a Roman woman; also: a well-known Roman family], "Claudianus, g.m. un poetic alixandrinean; iarăş: un împărat de la Roma" [a poet from Alexandria; also: an emperor from Rome], "decemviri, g.m. pl. zeace oameni mari, boiari, care au îndereptat Roma" [ten great noblemen, who made laws in Rome], "dictator, g.m. crai prea mare au fost în Roma, pre carele în vreame răscolită spre aceaea l-au ales ca toți de dînsul să spînzure” [a great ruler from Rome, who in times of rebellions was chosen to lead them all], "Gabinus, -i, g.m. un om mare de la Roma" [a great man in Rome], "Galba, g.f. [...] numele unui om de la Roma" [name of a man from Rome], "Gracchus, g.m. nume al unui pîrgari de la Roma" [name of a consul from Rome].

8“Cicero un vestit şi mărit boiar de la Roma şi înțelept înfrîmşețat vorovitori” [a famous and great nobleman in Rome and a wise and talented orator].

9"Horatius, g.m. un poetic liricusean şi satirisean" [a great writer of lyrics and satires].

10 "Ovidius, -i, g.m. numele unui poetic vestit" [name of a famous poet].

11 "Juvenalis, g.m. numele unui poetic satiric" [name of a satirical poet].

12 "Lucretius, g.m. un poetic de demult care s-au născut după Țițero la al doisprăzeacelea an” [an ancient poet who was born 12 years after Cicero].

13 "Livius, g.m. un istoriceari vestit, care de lucrurile făcute rimleneşti cu împodobire au scris" [a famous historian, who wrote in a beautiful manner about the Roman things].

14"Actor, g.m. numele al unui om în Virghilius" [name of a man in Vergilius], "Acutia, g.f. muiarea lui Virghilius" [the wife of Vergilius], "Alcanor, g.m. nume al unui om de care Virghilius pomeneaşte" [name of a man mentioned by Vergilius], "Almon, g.f. [...] un nume de păstori la Virghilius" [name of a shepherd in Vergilius], "Alphesibæus, g.m. nume al unui păstori în Virghilius" [name of a shepherd in Vergilius], "Alsus, g.m. un nume de păstori în Virghilius” [name of a shepherd in Vergilius], "Amaryllis, -idis, g.f. nume al unei mojice în cartea lui Virghilius" [name of an ordinary woman in Vergilius' book], "Andes, g.m. pl. un sat lîngă Mantuanal [sic!], în care Virghilius s-au născut” [a village near Mantuanal, where Vergilius was born], "Anthores, g.m. nume al unui om în Virghilius" [name of a man in Vergilius], "Bavius, g.m. un poetic neînvațat, pizmaş lui Virgilius" [name of a bad poet, opponent of Vergilius], "Bianor, g.m. nume al unui om in Virgilio" [name of a man...], "Choroebus, g.m. [...] numele unui copil nebunatec in Virgilio" [name of a frisky child...], "Corydon, g.m. un păstori în Theocritus și în Virghilius" [a shepherd in Theocritus and Vergilius], "Damoctas, g.m. nume al unui păstori la Virghilius" [name of a shepherd in Vergilius], "Didymaon, g.m. un faur vestit de care pomeneaşte Virghilius" [a famous blacksmith mentioned by Vergilius]. 
whose work he mentions the two epic poems, the Iliad ${ }^{15}$ and Batrachomyomachia; Corbea's dictionary abounds in events and characters from the Iliad and the Odyssey ${ }^{16}$, and also mentions "Batrachonyomarchia, război de broaşte şi de şoareci, adecă războiul broaştelor cu al şoarecilor, de care au scris Homerus" [war between frogs and mice, of which Homer wrote].

4.8. Greco-Latin mythology is also abundantly present in Corbea's text. What is particularly interesting is the fact that the author does not perceive it as a dimension of paganism, but rather as belonging to literary culture and poetic imagination, recording the data from the perspective of Renaissance florilegia ${ }^{17}$. He distances himself from the Antiquity, which remains an essential point of reference from a cultural perspective, not necessarily because of the conflicting dimensions of Christianity-paganism, but rather because he was essentially a modern spirit and realized that he was living in another era, an era that was

15 "Ilias, -dis, g.f. cartea lui Homerus de piiarderea Troadei” [Homer's book on the fall of Troy].
16“Achilles, g.m. fiiul lui Oeleus, care au fost hodnogi în războiul Troadei” [son of Peleus who was a commander in the Trojan War], “Æantium, g.n. oraş al Troadei” [town in Troy], “Agastrophos, g.m. fiuul lui Peon şi, în războiul de la Troada, mare viteazu” [son of Peon, brave warrior in the Trojan War], "Ajax, -cis, g.m. numele la doi greci viteazi în războiul Troadei, polecra unuia Telatonius, al altuia Oilesus" [name of two brave Greek men who fought in the Trojan War, of which one was called Telatonius, and the other Oilesus], "Alcander, g.m. unul dintre soțîi lițienești ai lui Sarpedon, pre carele în războiul Troadei Ulises l-au omorît" [one of Sarpedon's companions from Lycia, who was killed by Ulysses in the Trojan War], "Alethes, g.m. nume al unui om din Troada” [name of a man from Troy], “Andromache, g.f. muiarea lui Hector de la Troada” [the wife of Hector from Troy], "Antenor, g.m. numele al unui om mare de la Troada” [name of an important man from Troy], "antepilani înainte umblători aleş viteaji au fost la războiul Troadei” [brave soldiers who composed the first ranks in line of battle in the Trojan War], "Anthemion, g.m. tatăl lui Sişocus de la Troada” [father of Simoeisios from Troy], "Antilochus, g.m. fiiul lui Nestor în războiul Troadei, de la Memnos s-au omorît” [son of Nestor, killed by Memnos in the Trojan War], "Astynous, g.m. hearțeg troadean pre carele Diomedes l-au tăiat" [defender of Troy killed by Diomedes], "Aulis, -dis, g.f. oraş elinesc; unde seminţiile care au mărs supt Troada s-au adunat dempreună” [Greek town where the armies gathered to set off for Troy], "Berirthrus, g.f. un oraş de la Troada" [town from Troy], "Cajeta, g.f. nume al unii muieri de la Troada" [name of a woman from Troy], "Berytis oraş care să țîne de Troada" [town near Troy], "Dardanus, g.m. fiiul lui Iupiter şi al Electrei de pre care Dardania apoi s-au numit Troada" [son of Jupiter and Electra who gave the name of Dardania, later known as Troy], "Diomedes, g.m. craiul Etoliei şi în războiul Troadei hătnogi mare al grecilor sau elinilor" [Prince of Etolia and leader of the Greeks in the Trojan War], "Epeus, g.m. numele aceluia care au făcut calul cela mare de lemn de la Troada" [the name of the one who built the large wooden horse from Troy], "Glaucus, g.m. fiul lui Hippolocus în războiul Troadei” [son of Hippolocus from the Trojan War], "Helena, g.f. fata lui Tindarus, muiarea lui Menelau, pentru a căriia frîmseațe s-au pierdut Troada" [daughter of Tyndareus and wife of Menelaus, for whose beauty Troy was lost], "Adamastus, g.m. un ithacliian soț lui Ulises" [a companion of Ulysses from Ithaca], "Calypso, g.f. fata lui Oțeian la carea au fost Ulises” [daughter of Oceanus, to whom Ulysses went], "Elpenor, g.m. soț de călătorie al lui Ulises pre carele Țirțe cu cîteva [sic!] cu dîns l-au şimbat în porc” [companion of Ulysses who was turned into a pig by Circe], "Ithaca, g.f. ostrov la Marea Ionium în care au domnit Ulises" [island in the Ionian Sea, the homeland of Ulysses], "Polyphenus, -i, g.m. un uriiaş care au avut numai un ochi şi şi acela i l-au scos Ulises" [a giant who had only one eye, blinded by Ulysses], "Telegonus, g.m. un fii al lui Ulises de la Țirțe” [Ulysses' son from Circe], “Telemachus, g.m. fiul lui Ulises de la Penelope” [Ulysses' son from Penelope], “Theoclymenus, g.m. un spuitori de ceale viitoare, care au gîcit Penelopei venirea bărbatului său, a lui Ulises” [prophet who told Penelope about the return of her husband, Ulysses], "Scylla, g.f. [...] fata lui Forcus, care (precum scriu poeticii) s-au şimbat în stîncă de piiatră de mare sau în jivină cu formă ciudată care aşa urlă ca cîinele” [daughter of Phorcus who (as the poets say) turned into a sea rock or a beast-shaped monster who howls like a dog], etc.

17 “Atlas, -antis, g.m. un munte înalt în Mauritaniia, iară la poetici, un uriiaş mare care țîne ceriul în spate” [a high mountain in Mauritania which the poets describe as a giant who carries the sky on his shoulders], "Averna, g.n. pl. un aleşteu în țînutul Campaniei, pre care i-au zîs poeticii a fi poarta iadului” [a pond in the land of Campagna about which the poets say it is the gate to hell], "Dindymus, g.m. sing. in plur. dindima vîrfurile ceale înalte a munților de la Frighiia; la poetici s-au svințit mumînilor dumnezăilor" [the high peaks of the mountains in Phrygia; the poets call it the mother goddess], "Europa, -x, g.f. idem, item: fata lui Oțeanus după scrisoarea poeticilor” [daughter of Oceanus, as the poets say], "Geryon, g.m. crai şpaniolesc au fost pre care l-au omorît Hercules, care au avut trei capete, precum scriu poeticii” [Giant from Spain who had three heads, as the poets say, and who was killed by Hercules], "Hymen, g.m. dumnezăul nuntelor după scrisorile poeticilor" [god of marriage, as the poets say], "Jupiter, Jovis, g.m. văzduh, aer; iarăş: fiiul lui Saturnus pre care l-au țînut poeticii prea de sus a f”" [air, sky; or son of Saturn, the poets thought too highly of him], “Tantalus, g.m. fiiul lui Iupiter şi al Plutei, carele în iad (din părearea poeticilor) totodeuna însătează şi flamînzeaşte, săvai că pînă la grumaz stă în apă şi înaintea nasului spînzură mărul cel rodit, cu care, cînd va să trăiască, îndată să zmuceaşte de la dîns [son of Zeus and Plouto, who, as the poets say, is forever thirsty and hugry in hell, although he stays in a pool of water up to his neck and an and with an apple tree in front of him, with the fruit ever eluding his grasp]; hinc: tantalus, -a, -um”, etc. 
different from that of "bătrînii" [the ancient] or "cei de demult" [those from the past] ${ }^{18}$; "cei de demult", "bătrînii" and "poeticii" [the poets] represented a closed universe, another civilization and another world, so that a conflict between Christianity and the pagan Ancient world was out of discussion. Moreover, the same phrases could designate peoples that no longer existed or faded out in history, as well as objects of which we only read in the ancient books ${ }^{19}$.

We note thus that for Corbea, ancient Rome and Christian Rome did not represent conflicting images (Gherman, 2001) simply because the two aspects of the Eternal City evoked two different universes. This fact clearly points to the process of laicization of the Romanian culture, which starts at the point where the cultural and the religious dimensions no longer coincide ${ }^{20}$, the two worlds evoking different spaces.

4.9. If Italy and Greece are known primarily from information provided by the Greek-Latin literature, Europe (France and Germany, especially) is presented by means of pertinent information belonging to the modern times; thus, Nuremberg becomes the centre of the world: "Noriberga, g.m. oraș mare al Țărei Nemțești, care cu frumoasa zidire, cu bogățiia, cu neguțători, cu fealiuri de fealiuri de lucruri scumpe și cu oameni meșteri iaste vestit și nu o mint. Acesta, în toată Evropa, în Țara Nemțască alte orașuri biruind, cu Vinețiia frîncească [sic!] să priceaște. Acest oraș nu numai Țărei Nemțăști ci și toții Evrope în mijloc iaste" [large city of the German country, famous for its beautiful buildings, wealth, merchants, all sorts of precious things and great people. This city, more beautiful than any other in the German land, rivals Venice in France [sic!]. This city is located not only in the center of Germany, but also in the very heart of Europe], or “Norvegia, g.f. ținutul Evropei de cătră crivăț, care îl biruiaşte craiul danienesc” [Europe’s country in the direction of the north wind, ruled by the king of Denmark].

\subsection{The landmarks of the modern world are first and foremost the cultural ones: "Argentina, g.f. et}

18“Rhadamanthus, g.m. fiul lui Iupiter şi al Europei, derept şi vîrtos împărat al Liției, de unde poeticii îl țîn a fi împărat sufletelor din iad" [son of Zeus and Europa, fair and brave king of Lycia, of whom the poets say he was the judge of the souls in the underworld], "Cunina, g.f. bătrînii o au țînut a fi dumnezăoaie a copiilor înțelepți”" [the ancient people say she was the goddess of wise children], “Atropos, g.f. nepurcegătoare, adecă una dintru 3 parche, carele fieştecăruia de la dumnezău svîrşită viiață croiescu, (jerebiia) tortul îl taie. Bătrînii cei de demult precum au fost romanii şi elinii pre aceastea mai sus zise le-au numit a fi dumnezăoaie" [one of the three Moirai, who chose how people ended their life by cutting their threads. The ancient Greeks and Romans would call them goddesses], "daps, g.f. feali al jîrtvei au fost la cei de demult" [type of sacrifice for ancient people], "Druidæ, g.m. pl. înțelepții cei de demult ai frîncilor" [ancient wise men of the Celts], "lucuus, g.m. nume de bucate au fost la cei de demult" [ancient name for foods], "Marica dumnezău l-au țînut cei de demult a fi purtători de grija țărmurilor" [a god, of which the ancient men considered the protector of the shores], "Opigema, g.f. Iuno, pre care cei de demult o au socotit ajutătoare copiilor celor ce să nasc" [Juno, of which the ancient people considered the protector of new-born children], “Tænarus, g.m. pl. Tænara, g.n. un deal aproape de Spartha sau un loc sub dealul Malca unde iaste o groapă mare şi o peştere adîncă, îmbăsnată, care cei de demult o au socotit poarta iadului” [a hill in the vicinity of Sparta or a place under the hill of Malca where there is a big hole and a deep cave where the ancient people believed was the gate to hell], etc. The cultural reception of ancient mythology is also marked by the fact that more than often the authors whose writings contain relevant references related to it are also cited: "Tutilina, g.f. Varro et Nonius dumnezăiță s-au țînut a scutirei, a ferirei la romanii cei de demult" [Roman goddess considered responsible for protection], etc.

19 “liber, libri, g.m. pelița cea supțîre albă dinlăuntru a coajei lemnului pre care au scris cei de demult (adecă bătrînii)" [the white thin layer inside tree bark on which ancient people used to write], "albegnnina, g.n. pl. partea cea albă a mațelor vitelor, care dumnezăilor au jîrvuit cei de demult" [the white part of the intestines of cows sacrificed by the ancient people for the gods], “amystis, g.f. neamul băuturei de duşcă au fost la sîrbii cei de demult” [old Serbian drink], "daps, g.f. feali al jîrtvei au fost la cei de demult" [type of sacrifice for ancient people], "Hunni, g.m. pl. ungurii cei de demult" [the old Hungarians], "jazyges, g.m. pl. lăcuitorii cei de demult ai Țărei Ardealului" [the old inhabitants of Transylvania], "lucuus, g.m. nume de bucate au fost la cei de demult" [type of ancient food], "Marcomani, g.m. pl. cechii şi morăvanii cei de demult" [the ancient Czechs and Bohemians], "Metanastæ, g.m. pl. ardeleanii, lăcuitorii cei de demult ai Ardealului” [the old inhabitants of Transylvania], “myxon, g.m. feali al peaştelui pre care romanii cei de demult bucată mare l-au țînut a fi" [type of fish highly appreciated by the ancient Romans], "phalæ, g.f. pl. turn de lemn care cei de demult l-au zidit în locul de privirea jocului” [wooden tower built by the ancient people for watching the games], "philura, g.f. coaja cea dinlăuntru a teiului, pă care au scris cei de demult" [the inner layer of the linden tree bark on which ancient people wrote], "rogus, -i, g.m. grămadă de leamne pă care cei de demult au ars trupurile ceale moarte" [pile of wood on which ancient people used to burn the bodies of the dead].

${ }^{20}$ One can observe the manner in which in the previous Romanian culture the prevalent religious dimension produced a selection of values depending on its necessities. 
Argentoratum tare oraș al Țărei Nemțești lîngă apa Rhenus, în țînutul Alsației. Acolo ca acela înalt turn iaste și bisearecă înfrîmșețată, cît în Europa altă bisearică sau turn aseamine acestora nu iaste. Iaste iarăș acolo o academie vestită, în care de demult mulți înțelepți oameni s-au învățat” [a German town near the Rhine River, in Alsace. There you find a tall tower and a beautiful church as nowhere else in the whole Europe. There is also a famous Academy where many famous people studied in the past], "Altorsium, g.n. orăşăl în țînutul domnilor norimbergheani, în care acest noriberghean svat cinsteș bogată academie au zidit în numărul anilor 1575" [ small town of the land of the Nuremberg where a rich academy was built in the year 1575], "Herbona, g.f. orașîn țînutul Nasoviei al Țării Nemțăști, în care iaste școală vestită, care să priceaște cu academiile și pre care le și învince" [German town in the region of Nassau where there is a famous school, even better than the academies], "Marpurgum oraș al Țărei Nemțești în țînutul Hassiei în care iaste academie vestită" [German town in the region of Hessen, where there is a famous academy]. The information related to culture in the period following Antiquity is rather scarce: the name of Venerable Beda is mentioned among others ("Beda, g.m. în Țara Angliei au fost dascal învățător de Scriptura Svîntă” [he taught the Holy Scriptures in England]) along with composer Orlando di Lasso ("Lasus, g.m. cel mai dintîi care au scris de muzică" [the first one to write music]); Boccaccio is only mentioned in relation to his historical works: "Boccatius, g.m. un istoriceari italiian" [an Italian historian].

Teodor Corbea's humanist perspective is expressed, as in the case of his contemporaries, by the fact that he emphasizes the Latin character of the Romanian language. This perspective was shared by numerous western men of culture who came into contact with the Romanians, being also embraced by the Romanian historiography starting with the $17^{\text {th }}$ century (Grigore Ureche, Miron Costin, Constantin Cantacuzino, Dimitrie Cantemir, etc.). Unlike the other scholars, Teodor Corbea does not state it directly nor does he mention the Roman descent of his people explicitly. By commonly identifying the ancient populations of the Antiquity with those who inhibited the respective region in his time, he extrapolates to the Romanian territory: "Daci, g.m. pl. rumînii" [Romanians], "Getæ, g.m. pl. rumînii" [Romanians], "geticus, -a, -um rumînesc, -ă, din Țara Rumînească” [Romanian, of the Romanian country], although the same population is also identified differently as: "Dacæe, g.m. pl. seminții de la Sțithiia" [people from Scythia].

\section{The influence of the Latin model}

The author is, however, well aware of the Latin origin of certain Romanian words. Due to the numerous similarities between Latin and Romanian he provides a list that is considerably larger than the ones previously elaborated by Grigore Ureche and Miron Costin, an aspect which proves an obvious awareness of the Romance character of the language. Quoting just from the first pages of the dictionary, we identify: "abellina, g.f. alună", "abjugo, -as dezjug”, "abjuratio jurare”, “abnepos, g.m. strănepot”, "abneptis, g.f. strănepoată", "abnodo, -as clinciurile, nodurile curăţ", "abrodo, -is, -ere roz", "abrumpo, -is, -ere rumpu", "abscondo, -is, -ere ascunz, tăinuiesc", "absconsio, -onis ascundere", "absconsor, g.m. ascunzători", "absimilis, -e usebit, -ă, nu-aseamine", "absisto, -is, -ere stau, las", "absorbeo, -es, -bui, -psi sorbu”, “abstergeo, -es, - ere ștergu”, “abstersio, g.f. șteargere”, “abstersus, -a, -um șters, -ă”, “accresco, -is, -ere cresc", "acer, acris et acra acru”, "acor, g.m. înăcrime”, "acor, g.m. înăcrime”, "acuncula, $-\mathfrak{x}$, g.f. acşor”, "acus, -us, g.f. ac", "adaquo, -as vite adăp", "addenseo, -es desăsc", "addesso, -es desăsc", "adductio, g.f. ducere, povățuire spre ceva", "adfringo, -is frîngu", "adgemo, -is gemu", "ajuro, -as foarte mă juru", "ajuto, -as ajutu”, "adjutor ajutători”, "adjutorium ajutori”, "adjutrix ajutătoare”, “adjutus, -a, -um ajutat, -ă”, “adjuvo, -as ajutu”, “adlatro, -as latru”, “admiratio, g.f. minune, ciudă, mirare", "admirator, m. minunători, mirători”, "admiror, -aris mă mir, mă minunez", "admugio, -is, -ire zbieru, mugescu", "adporto, -as portu, aducu", "adrado, -is razu”, "adrodo, -is rozu”, "adsideo, -es, -ere șezu lîngă ceva”, "adsido, -is așezu lîngă ceva, mă sloboz", “arma, g.f. armă”, "armus, g.m. armă, umere", "arquatus, -a, -um în chipul arcului plecat, strîmb, -ă”, "arquites, g.m. pl. arcari, războitori cu arce", “arquus, g.m. arc”, etc.

5.1. Since the Hungarian language does not have the category of gender for adjectives, Corbea uses the 
Latin language model for the Romanian equivalents as far as this grammatical category is concerned: "affirmatus, -a, -um mărturisit, -ă, întărit, -ă", "afflatus, -a, -um suflat, -ă", "alacer, alacris, alacra veasel, voios, -ă, sîrguitori, -re, isteț, -ță, ager, -ră”, “algidus, -a, -um friguros, -ăa, geros, -ă" "algificus, -a, -um friguitori, -re, geruitori, -re" etc. Occasionally, in order to point to the existence of genderrelated forms, he uses the phrase "pă 3 neamuri” [in three gender forms]: "ædonius, -a, -um trațienesc, -ă; iarăş: de preveghitoare (pă 3 neamuri)", “æneus, -a, -um de aramă (pă 3 neamuri)”, “æquanimus, -a, -um cu inimă lină (pă 3 neamuri)", "æedilitius, -a, -um spre boieriia ziditoriului meşter lucru sau altceva (şi aşa pă trei neamuri)", etc., mentioning the fact that adjectival forms are variable even in the case of periphrastic phrases, in which this variability is not actually traced in Romanian: "acernus, -a, -um de arţari (pă trei neamuri)", “ædonius, -a, -um trațienesc, -ăa iarăș: de preveghitoare (pă 3 neamuri)”, “ærius, -a, -um văzduhos, -ă, de aer (pă 3 neamuri)", “affinis, -e vecin, -ă, de aproape (pă 3 neamuri)", "æquævus, -a, -um de o vreame (pă trei neamuri)", "æxtnæus, -a, -um din muntele Siliției (floare) și așa umblă pă trei neamuri”. Aware of the similarity with the Latin language and consequently, the difference from the Hungarian language, he notes: "æxtolus, -a, -um de la Etoliia om sau altceva, fieștece neam va hi (pentru că așa umblă la rumîni acest feali de nume adăogători)" [because this is how the Romanians use this name]. These differences between Romanian and Latin make him occasionally introduce explanations such as: "dimidius, -a, - -um jumătate (pă 2 neamuri rumînești)".

5.2. The Latin lexis of the dictionary motivated the author to consciously make use of the Romanian word derived from the respective etymon, even if those were rare words. Such a situation is illustrated by the verb mursăca, used only in connection with the Latin verb morsicare 'to bite': "morsicatim, adv. mușcățeaște, mursăcățeaște”, "morsio, g.f. mușcare, mursăcare”, "morsiuncula, g.f. mușcăturea, mursăcăturea”, "morsus, -us, g.m. muşcare, mursăcatul”, “morsus, -a, -um mușcat, -ă, mursăcat, -ă”; elsewhere in the dictionary, Teodor Corbea uses the Romanian verb a muşca 'to bite', even when it carries prefixes specific to mordere: "admordeo, -es mușcu", "commordeo, -as mușcu", "demordeo, -es mușcu jos", "mordax, -cis, g.o. mușcători, -re, usturători, -re, pișcători”, "mordacitas, g.f. mușcătură, pișcătură”, "mordeo, -as mușcu”, "mordicibus pro morsibus, dixit Plautus cu mușcători”, “mordico, -as mușcătorescu”, "mordicus, adv. mușcînd, mușcățeaște”. The author's awareness of the Latin character of the language is also indicated by his choice of rarely used regional terms suggested by the Latin words, for which he also provides additional explanations: "colostra, g.f. corastră, laptele cel dintîi după naștere" [colostrum, the milk produced right after birth]. Following the model provided by the Latin text, Corbea even re-creates some forms that are phonetically closer to the Latin word, as in capestere ("capisterium, g.n. capesteare, ciur"), although elsewhere in the dictionary the same term occurs as căpestere: "labrum, g.n. buză; iarăș: scafă, căpestere, troacă”, "mactra, g.f. moldă, căpesteare de copt, căpesteare de frămîntat", "magis, -dis, g.f. moldă, căpesteare de frămîntat”, etc.

\section{Conclusions}

The question that obviously comes to mind, namely for what purpose did Bishop Mitrofan of Buzău need this dictionary?, has several answers, all equally valid. Mitrofan, the former Bishop of Huși and close collaborator of Metropolitan Dosoftei, who, after coming to Walachia, contributed to the printing of the Bible from Bucharest, was a highly cultivated man who valued and needed access to texts written in Latin. He had a special interest in the greatest Latin collection of the lives of saints, Vita sanctorum, which he used for printing the Menaion in 1698. Since a simple linguistic preference can justify the identification of a writer, the phrase cicişi colea meaning 'here and there', which can be identified in the texts of that time only in Teodor Corbea's work and in some of the lives of saints in the Menaion from Buzău, entitles us to believe that he was not merely a paid translator of the dictionary, but also a collaborator of the monumental Menaion. 


\section{Bibliography}

DUL = Albert Szenczi Molnár, Dictionarium Ungarico-Latinum, Heidelberg, 1621.

Gherman, A.-M. (2001). Cele două Rome ale lui Teodor Corbea, in "Romania Orientale”, XIV, Bagatto Libri, Roma, p. 125141.

Gherman, A.-M. (2019). Studiu introductiv, in Ioan Zoba din Vinț, Cărare pre scurt, Muzeul Național al Unirii, Alba Iulia. Pippidi, A. (2005). Noi mărturii despre relațiile lui Rákóczi cu românii, in “Studii şi materiale de istorie medie”, XXIII, p. 281300.

Vocab. 1840-1841 = P. Poenaru, F. Aaron, G. Hill, Vocabular franțezo-românesc după cea din urmă ediție a dicționarului de Academia Franțozească, volumes 1-2, Tipografia Colegiului „Sfîntul Sava”, București, 1840-1841.

Seche, M. (1966). Schiță de istorie a lexicografiei românești, volumes I-II, Editura Științifică, București.

TLG = Henricus Stephanus, Thesaurus grece lingue, Paris, 1572. 